Vol. 10 (2001): 335-346.

\title{
Estimated metabolizable energy yields of perennial and annual grass swards compared with those of spring barley and oat
}

\author{
Oiva Niemeläinen and Markku Kontturi \\ MTT Agrifood Research Finland, Plant Production Research, FIN-31600 Jokioinen, Finland, \\ e-mail: oiva.niemelainen@mtt.fi
}

Lauri Jauhiainen

MTT Agrifood Research Finland, Data and Information Services, FIN-31600 Jokioinen, Finland

Oiva Nissinen

MTT Agrifood Research Finland, Lapland Research Station, Tutkijantie 28, FIN-96900 Saarenkylä, Finland

The dry matter yields of cultivar trials (from 1976 to 1998 at 15 sites in Finland) of perennial grass sward (meadow fescue (Festuca pratensis) cv. Boris), annual grass sward (Italian ryegrass (Lolium multiflorum), cv. Barmultra and Mitos), spring barley (Hordeum vulgare cv. Otra, Arra, Arve) and oat (Avena sativa cv. Veli) were used to estimate metabolizable energy yields (MEY) by using the feeds metabolizable energy concentration values (MJ/kg DM) from ruminant feed tables. Harvest index (HI) of barley and oat was set to 50\%, and straw yields and whole crop cereal silage (WCCS) yields were generated from grain yields accordingly. The MEY in the third year of perennial grass (81.4 GJ/ ha) was significantly lower than that in the first $(90.0 \mathrm{GJ} / \mathrm{ha})$ and second years $(90.7 \mathrm{GJ} / \mathrm{ha})$. However, on average, the one to three year old perennial grass swards had significantly higher MEY than the annual grass swards ( 87.7 vs. $83.3 \mathrm{GJ} / \mathrm{ha}$, respectively). The MEYs of perennial and annual grass swards were substantially higher than the MEY of barley grain $(52.7 \mathrm{GJ} / \mathrm{ha})$ and oat grain $(47.8 \mathrm{GJ} /$ ha). When the total herbage of cereals, i.e. straw and grain, was used in the calculations, at a ME value of $6.0 \mathrm{MJ} / \mathrm{kg}$ dry matter (DM) for straw, the MEY of barley rose to $75.8 \mathrm{GJ} / \mathrm{ha}$ and that of oat to $72.6 \mathrm{GJ} / \mathrm{ha}$. Additionally, the MEY of barley was estimated in the WCCS production situation by converting total herbage to MEY by using ME value $9.9 \mathrm{MJ} / \mathrm{kg}$ DM. The MEY of barley in the WCCS calculations was $77.4 \mathrm{GJ} / \mathrm{ha}$, which was significantly lower than the MEY of annual and perennial grass swards. The MEY of barley was a) $60 \%$, b) $86 \%$, and c) $88 \%$ of the average MEY of one to three year old perennial grass sward when the MEY of barley was calculated according to a) grain, $b$ ) grain + straw, and c) whole crop cereal silage. Perennial grass sward was the most productive of the studied crops in metabolizable energy production for ruminants.

Key words: crop yield, feed grains, fodder crops, forage, grass silage, herbage, ley farming, productivity, whole crop harvesting, whole crop silage

(C) Agricultural and Food Science in Finland

Manuscript received May 2001 


\section{AGRICULTURAL AND FOOD SCIENCE IN FINLAND}

\section{Niemeläinen, O. et al. Productivity of swards, barley and oats as feed for ruminants}

\section{Introduction}

Ruminants are highly versatile in using feed. Therefore, their diet may contain a large variety of feed sources. In Finland, grass silage is the primary feed source in dairy production, supplemented by concentrates according to the milk production of the animals. In 1999, on average $56 \%$ of the feed units of dairy cattle originated from silage, hay and pasture, $20 \%$ from cereal grain, and $22 \%$ from concentrates, including protein supplements (Maaseutukeskusten Liitto 2001). Recently, whole crop cereal silage (WCCS) has received growing interest as a mean to decrease feed production costs. Turunen (2000) calculated that the cultivation of WCCS rather than cereal grain would increase profitability of dairy farms. A single machinery chain may be used for WCCS and grass silage, while specialized equipment has to be used when combining the cereals. In addition, the most recent Finnish studies in milk production have shown that WCCS represents an alternative feed source for dairy cattle (Jaakkola 2000). Finnish data on WCCS indicate a high yield potential, > 10000 kg DM/ha (Kommeri and Kontturi 1981, Agricultural Research Centre of Finland and Boreal Plant Breeding 1999). However, yield data of Finnish WCCS are scarce. Grass production in Finland is characterized by having short-term swards, - usually younger than five years. Only four percent of the total grassland area is devoted to permanent grassland (Ministry of Agriculture and Forestry 2000). This increases the justification for comparing grass production in relation to cereal production because both production systems are based on high inputs of labour, fertilisers and capital.

Our objective in this study was to compare productivity of annual and perennial swards and barley and oat when grown under Finnish conditions as feed for ruminants. We used the existing data from official cultivar trials to estimate the dry matter yield of WCCS in Finland (WCCS yields were generated from grain dry matter (DM) yield by harvest index 50\%). However, comparing the yield of crops, as different as grain and silage, is complicated by the difficulty to use an appropriate unit to compare the yields. In this study we calculated metabolizable energy yield (MEY) from DM yield. The dataset of official cultivar trials comprised a large number of results obtained from various sites in Finland. Crops were cultivated according to recommended cultivation practices at the various sites. The species were not cultivated in the same experiments, but we included in the study only data from sites where experiments of at least three of the studied species (barley (Hordeum vulgare L.), oat (Avena sativa L.), Italian ryegrass (Lolium multiflorum Lam.), meadow fescue (Festuca pratensis Huds.) had been conducted simultaneously. Within a site, we assumed that each species had been cultivated under suitable conditions. Thus, we assumed no bias in favour of a particular species.

\section{Material and methods}

\section{Information of the variety testing experiments}

The data originated from official cultivar trials carried out by MTT Agrifood Research Finland in co-operation with plant breeding companies testing sites. The experiments were carried out according to good agricultural practices and recommended management procedures were followed for each species. The guidelines on variety testing changed only slightly for the period during which the data were obtained. The guidelines on conducting cultivar trials were described by Järvi et al. (1998).

The data used in this study were recorded from 1976 to 1998 and originated from 15 sites (Table 1). Barley and oat were sometimes grown in two trials on different soil types in the same year. In those cases, the average yield from both trials was used. However, data from special barley experiments on low $\mathrm{pH}$ soils at Ylistaro 
Vol. 10 (2001): 335-346.

Table 1. Trial sites and years when data was obtained and number of results from each trial sites of the studied species.

\begin{tabular}{|c|c|c|c|c|c|c|c|c|c|c|}
\hline Site & Location & Years & PG1 & PG2 & PG3 & $P G T$ & $\mathrm{AG}$ & Barley & Oats & Total \\
\hline Tikkurila & $60^{\circ} 18 \mathrm{~N}$ & 1976-80 & 3 & 5 & 4 & 12 & 0 & 4 & 3 & 19 \\
\hline Tuusula & $60^{\circ} 25 \mathrm{~N}$ & 1976-98 & 7 & 6 & 6 & 19 & 1 & 21 & 17 & 58 \\
\hline Jokioinen & $60^{\circ} 49 \mathrm{~N}$ & 1978-98 & 14 & 13 & 13 & 40 & 11 & 20 & 20 & 91 \\
\hline Hahkiala & $61^{\circ} 09 \mathrm{~N}$ & 1976-96 & 13 & 13 & 13 & 39 & 3 & 15 & 15 & 72 \\
\hline Kangasala & $61^{\circ} 28 \mathrm{~N}$ & 1977-88 & 5 & 4 & 3 & 12 & 1 & 4 & 8 & 25 \\
\hline Mouhijärvi & $61^{\circ} 31 \mathrm{~N}$ & 1977-96 & 2 & 1 & 1 & 4 & 0 & 17 & 19 & 40 \\
\hline Mikkeli & $61^{\circ} 40 \mathrm{~N}$ & 1976-98 & 11 & 10 & 7 & 28 & 3 & 17 & 10 & 58 \\
\hline Tohmajärvi & $62^{\circ} 14 \mathrm{~N}$ & 1976-96 & 11 & 10 & 10 & 31 & 20 & 18 & 19 & 88 \\
\hline Laukaa & $62^{\circ} 19 \mathrm{~N}$ & 1976-98 & 5 & 4 & 3 & 12 & 0 & 22 & 22 & 56 \\
\hline Ylistaro & $62^{\circ} 57 \mathrm{~N}$ & 1976-98 & 7 & 7 & 4 & 18 & 15 & 19 & 22 & 74 \\
\hline Maaninka & $63^{\circ} 09 \mathrm{~N}$ & 1976-98 & 13 & 12 & 11 & 36 & 0 & 18 & 22 & 76 \\
\hline Sotkamo & $64^{\circ} 01 \mathrm{~N}$ & 1982-98 & 8 & 7 & 6 & 21 & 10 & 0 & 0 & 31 \\
\hline Ruukki & $64^{\circ} 40 \mathrm{~N}$ & 1976-98 & 12 & 10 & 9 & 31 & 23 & 21 & 21 & 96 \\
\hline Muhos & $64^{\circ} 49 \mathrm{~N}$ & 1976-88 & 4 & 4 & 3 & 11 & 1 & 3 & 0 & 15 \\
\hline Rovaniemi & $66^{\circ} 35 \mathrm{~N}$ & 1976-98 & 14 & 10 & 6 & 30 & 18 & 23 & 0 & 71 \\
\hline Total & & 1976-98 & 129 & 116 & 99 & 344 & 106 & 222 & 198 & 870 \\
\hline
\end{tabular}

PG1, PG2, PG3, PGT = first, second and third year perennial grass (Meadow fescue) sward and perennial grass in total, $\mathrm{AG}=$ annual grass (Italian ryegrass) sward

were excluded from the dataset. Perennial grass was, on some occasions, sown in three experiments (first, second and third year sward) at the same site in the same year. The results for perennial grass were calculated according to the age of the sward.

Trial design was in most cases a completely randomized block with four replications. Grasses and cereals were sown by using the same equipment. Ten rows at $12.5 \mathrm{~cm}$ row width were sown. Plot length ranged from $8 \mathrm{~m}$ to $10 \mathrm{~m}$. Crops in plots were sown and harvested by using appropriate experimental equipment. In the variety trials, the yield of cereals is given at $85 \%$ DM. For this study the yields were converted to $100 \%$ DM. However, the net area of plot on which the yield is calculated differed between cereals and grasses. In cereal experiments the net plot width was $1.375 \mathrm{~m}$ (11 row widths) but in the grass experiments it was $1.50 \mathrm{~m}$ (12 row widths). This difference, which inflates cereal yields by $9 \%$ in comparison with grass yields, is based on the observation that grasses can completely utilize the $0.25 \mathrm{~m}$ space between plots while the erect cereals can only partially utilize the space.

The perennial and annual grass swards were usually harvested three times per season. Nitrogen was applied to the grasses at $100 \mathrm{~kg} \mathrm{~N} / \mathrm{ha}$ in spring and after the first cut, and at $50 \mathrm{~kg} \mathrm{~N} / \mathrm{ha}$ after second cut if the stand was harvested three times. The maximum $\mathrm{N}$ application in a season was $250 \mathrm{~kg} \mathrm{~N} / \mathrm{ha}$ for perennial grass and $300 \mathrm{~kg}$ $\mathrm{N} /$ ha for annual grass if four cuts were taken. The harvest of annual and perennial grasses took place at the silage harvesting stage (from 5 to $10 \%$ of the panicles had emerged at the first cut in spring; the cuts of the regrowth were scheduled so that in perennial grass the last cut would take place at the end of August/early September). Perennial grass experiments lasted three harvest years. Fresh yield was measured per plot and a composite sample of four replications was taken for dry matter and botanical analysis. In the cereal experiments only grain yield was measured. The nitrogen fertilizer application to cereals ranged from $40 \mathrm{~kg} \mathrm{~N} / \mathrm{ha}$ (organic soils) to $110 \mathrm{~kg} \mathrm{~N} / \mathrm{ha}$ (mineral soils). 


\section{AGRICULTURAL AND FOOD SCIENCE IN FINLAND}

\section{Niemeläinen, O. et al. Productivity of swards, barley and oats as feed for ruminants}

\section{Species and cultivars}

Meadow fescue was chosen as a representative perennial grass species as it was harvested at the silage harvesting stage in the cultivar trials. In Finland, Italian ryegrass is cultivated as a springsown annual crop, and harvested from three to four times in the growing season. Traditionally it is used in situations when forage is needed to substitute for the losses caused by winter damage to perennial grass stands. Barley and oat are the main cereal feed crops in Finland. Nearly all barley and oat are harvested for grain. Only spring barley and oat are cultivated in Finland.

In this study we aimed to fix the cultivar effect and, therefore, we used data for the same cultivar whenever it was possible. This was done by selecting cultivars that had been standard in the cultivar-testing programme. To have data for the species over the whole study period, we used Italian ryegrass cv. Barmultra in 1976-1989 and Mitos in 1990-1998. The meadow fescue cultivar Boris and oat variety Veli were sown throughout the study period. For barley, we used three cultivars, i.e. Otra (1976-1979), Arra (1976-1986) and Arve (1987-1998). All these cultivars were early and cultivated throughout Finland.

\section{Conversion of dry matter yield to metabolizable energy yield}

Yield was recorded in cultivar trials as $\mathrm{kg} \mathrm{DM} /$ ha. However, DM yield is not a feasible unit when comparing the effect of production of different species in livestock feeding. When rations for livestock are compiled, it is more appropriate to use metabolizable energy (ME), measured in $\mathrm{MJ} / \mathrm{kg}$ DM. To standardize the yield unit for all crops, we converted the DM yields to metabolizable energy yield (MJ/ha), based on energy values in ruminant feed tables (Tuori et al. 2001). Metabolisable energy in the Finnish feed tables is calculated with the British method presented e.g. in the following publication: MAFF 1984 (see Tuori et al. 2001). The digestibility values are based on data from large number of digestibility trials carried out with rams at the MTT Agrifood Research Finland. The digestibility values of grain and in some cases of grass silage have been calculated by regression functions which are based on the digestible trial material (see Tuori et al. 2001). In the feed tables each single feed may have various ME values according to the quality of the feed. In this study, we used values that corresponded to ME of average- or high-quality feed (Table 2). We used identical ME values for Italian ryegrass and meadow fescue.

In the cultivar trials only the grain yield of cereals was measured. Therefore, we used a set harvest index (HI) of 50\% for barley and oat to calculate the straw yield and consequently total DM yield in WCCS. When calculating the average ME value for grain and straw in the comparison presented in the column B in Table 2, the $\mathrm{ME}$ value for total above-ground herbage for barley was $9.7 \mathrm{MJ} \mathrm{kg}^{-1} \mathrm{DM}((13.4+6.0) / 2=9.7)$ and $9.15 \mathrm{MJ} \mathrm{kg}^{-1} \mathrm{DM}((12.3+6.0) / 2=9.15)$ for oat. The determination of the metabolizable energy value of whole crop cereal silage is difficult. In the feed table three values are given, 9.3, 9.9 and $10.7 \mathrm{MJ} / \mathrm{kg} \mathrm{DM}$, according to the neutral detergent fibre content of the crop. We used the value $9.9 \mathrm{MJ} / \mathrm{kg} \mathrm{DM}$ in our study.

\section{Statistical methods}

As a prerequisite for the cultivar trial results to be included in our study data we set that at least three of the studied four species were grown at the same trial site on same year. However, the species were not grown in the same experiments or in the same field. It was not possible to take into account variation among fields. Thus, there was considerable random variation between results from separate trials at any one site in the same-year. The statistical model we used was identical to that for cultivar trials for a single plant species (Patterson and Nabugoomu 1992) where the plant species took the place of the 
Vol. 10 (2001): 335-346.

Table 2. Feed values of the studied forage species used in calculations to convert the dry matter yield to yield of metabolizable energy (see text and Tuori et al. 2001).

\begin{tabular}{|c|c|c|c|c|}
\hline Forage & $\begin{array}{c}\text { Metabolizable energy } \\
\text { MJ / kg DM }\end{array}$ & $\begin{array}{l}\text { Digestibility of } \\
\text { Organic Matter }\end{array}$ & D-value & $\begin{array}{l}\text { Used in Table } 3 \\
\text { In comparison }\end{array}$ \\
\hline Fresh grass, silage stage & 11.0 & 76 & 69 & A \\
\hline Grass silage, $1^{\text {st }}$ cut & 10.9 & 74 & 68 & $\mathrm{~B}$ and $\mathrm{C}$ \\
\hline Grass silage, regrowth & 10.2 & 71 & 64 & $\mathrm{~B}$ and $\mathrm{C}$ \\
\hline Barley, grain & 13.4 & 85 & 83 & $\mathrm{~A}$ and $\mathrm{B}$ \\
\hline Oat, grain & 12.3 & 75 & 72 & $\mathrm{~A}$ and $\mathrm{B}$ \\
\hline Straw of barley and oat & 6.0 & 46 & 43 & $\mathrm{~B}$ \\
\hline Whole crop cereal silage & 9.9 & - & 69 & $\mathrm{C}$ \\
\hline
\end{tabular}

cultivar in the model. The yield of MEY (GJ/ha) was analysed by using the following model:

$$
\begin{aligned}
\mathrm{y}_{\mathrm{ijk}}= & \mu+\text { site }_{\mathrm{i}}+\text { year }_{\mathrm{j}}+(\text { site } \times \text { year })_{\mathrm{ij}}+ \\
& \text { treatment }_{\mathrm{k}}+\left({\text { treatment } \times \text { site })_{\mathrm{ik}}}+\varepsilon_{\mathrm{ijk}}\right.
\end{aligned}
$$

Where $\mu$ was the grand mean. Site $_{i}$, year ${ }_{j}$, and $(\text { site } \times \text { year })_{\mathrm{ij}}$ were normally distributed random effects of site, year and site-by-year interaction. Treatment $_{\mathrm{k}}$ was the fixed effect of plant species, where the three different ages of the meadow fescue swards were used as different treatments. (Treatment $\times$ site $)_{\mathrm{ik}}$ was the normally distributed random effect of treatment-by-site effect. Partially this effect was a consequence of imperfect randomization. In practice this meant that some treatments were systematically placed in better fields than others at certain sites, but the treatment by site interaction takes this effect into account. The treatment-by-year interaction was used in the model also, but it was neither statistically significant nor practically important. Therefore, it was not included in the final model. The $\varepsilon_{\mathrm{ijk}}$ was the normally distributed residual effect. The estimated variance of the residual effect was approximately ten times larger than the variance in cultivar experiments of individual plant species. However, the sample size was so large that the practically important differences can be established. All random effects were mutually independent.

Sensitivity of species' MEY to environmental conditions was analysed using a simple regression model proposed by Finlay and Wilkin- son (1963). The MEYs were computed according to the calculation B presented in Table 3; in cereals grain plus straw yield and in grass swards first cut and regrowth differed in ME concentration.

Assumptions of the statistical models were checked graphically: box-plots for normality of errors and plots of residuals for constancy of error variance (Neter et al. 1996). Parameters of the models were estimated by the restricted maximum likelihood (REML) estimation-method by using the SAS release 8.1 for Windows, and the MIXED procedure (Littell et al. 1996).

\section{Results}

\section{Dry matter yields}

We did not analyse the dry matter yields with the statistical model. However, DM yields can be calculated from the MEYs. The average DM yields of perennial and annual grass sward was 8330 and $7979 \mathrm{~kg} \mathrm{DM} / \mathrm{ha}$, and the grain yield of barley and oat was 3934 and $3888 \mathrm{~kg} \mathrm{DM} / \mathrm{ha}$, respectively. These DM yields are computed from the MEYs presented in the column A in Table 3. When taking into account the fixed harvest index of $50 \%$, the total above-ground herbage of barley was $7868 \mathrm{~kg} \mathrm{DM} / \mathrm{ha}$ and of oat $7776 \mathrm{~kg} \mathrm{DM} / \mathrm{ha}$. The estimated total herbage DM of barley was $94 \%$ of the DM yield of per- 


\section{AGRICULTURAL AND FOOD SCIENCE IN FINLAND}

\section{Niemeläinen, O. et al. Productivity of swards, barley and oats as feed for ruminants}

Table 3. Metabolizable energy yield (GJ/ha) of annual (Italian ryegrass) and perennial grass (Meadow fescue) swards, barley and oat when their dry matter yields were converted to metabolizable energy on basis of A) grain yield of cereals and as fresh cut grass, B) grain plus straw yield in cereals and first cut graded with $10.9 \mathrm{MJ} / \mathrm{kg}$ DM and regrowth with $10.2 \mathrm{MJ} /$ $\mathrm{kg} \mathrm{DM}$ of grass, and C) cereal herbage yield (grain plus straw) graded as whole crop silage with $9.9 \mathrm{MJ} / \mathrm{kg}$ DM and grass as in calculation B. For conversion basis in calculations A, B and C see Table 2.

\begin{tabular}{|c|c|c|c|c|c|c|}
\hline Conversion formulas & $\mathbf{A}$ & & B & & $\mathbf{C}$ & \\
\hline Data from 15 trial sites & \multicolumn{2}{|l|}{$\begin{array}{l}\text { Grass: } \\
\text { fresh } \\
\text { Cereal: } \\
\text { grain only }\end{array}$} & $\begin{array}{c}\text { Grass: } 1^{\text {st }} \text { cut } \\
\text { and regrowth } \\
\text { Cereals: grain + } \\
\text { straw }\end{array}$ & \multicolumn{3}{|c|}{$\begin{array}{c}\text { Grasses: } 1^{\text {st }} \text { cut } \\
\text { and regrowth } \\
\text { Cereals: Whole crop } \\
\text { cereal silage }\end{array}$} \\
\hline Species & GJ / ha & s.e.m. ${ }^{\mathrm{a}}$ & GJ / ha & s.e. $\mathrm{m}^{\mathrm{a}}$. & GJ / ha & s.e.m ${ }^{\mathrm{a}}$. \\
\hline Perennial grass, $1^{\text {st }}$ year & 95.1 & 3.0 & 90.0 & 3.1 & 91.0 & 3.1 \\
\hline Perennial grass, $2^{\text {nd }}$ year & 94.2 & 3.1 & 90.7 & 3.1 & 90.7 & 3.2 \\
\hline Perennial grass, $3^{\text {rd }}$ year & 85.6 & 3.1 & 81.4 & 3.2 & 81.4 & 3.2 \\
\hline Perennial grass, $1-2$ years & 94.6 & 2.9 & 90.9 & 2.9 & 90.8 & 3.0 \\
\hline Perennial grass, $1-3$ years & 91.6 & 2.9 & 87.7 & 2.9 & 87.7 & 2.9 \\
\hline Annual grass & 87.8 & 3.2 & 83.3 & 3.3 & 83.3 & 3.3 \\
\hline Barley & 52.7 & 3.0 & 75.8 & 3.0 & 77.4 & 3.0 \\
\hline Oat & 47.8 & 3.0 & 72.6 & 3.0 & 78.8 & 3.1 \\
\hline
\end{tabular}

Differences and statistical significance in the table above:

\begin{tabular}{lcccccc}
\hline Conversion formulas & A & & B & & C & \\
\hline Comparisons between species & Difference & P-value & Difference & P-value & Difference & $P$-value \\
\hline Perennial 1 vs. perennial 2 & 1.0 & 0.63 & 0.3 & 0.89 & 0.3 & 0.89 \\
Perennial 1 vs. perennial 3 & 9.5 & $<0.001$ & 9.6 & $<0.001$ & 9.6 & $<0.001$ \\
Perennial 2 vs. perennial 3 & 8.5 & $<0.001$ & 9.3 & $<0.001$ & 9.3 & $<0.001$ \\
Perennial 1-2 vs. annual grass & 6.9 & $<0.001$ & 7.6 & $<0.001$ & 7.6 & $<0.001$ \\
Perennial 1-3 vs. annual grass & 3.9 & 0.09 & 4.4 & 0.02 & 4.4 & 0.03 \\
Perennial 1-2 vs. barley & 41.9 & $<0.001$ & 15.1 & $<0.001$ & 13.5 & $<0.001$ \\
Perennial 1-3 vs. barley & 38.9 & $<0.001$ & 11.9 & $<0.001$ & 10.3 & $<0.001$ \\
Perennial 1-2 vs. oat & 46.8 & $<0.001$ & 18.2 & $<0.001$ & 12.0 & $<0.001$ \\
Perennial 1-3 vs. oat & 43.8 & $<0.001$ & 15.1 & $<0.001$ & 8.9 & $<0.001$ \\
Annual grass vs. barley & 35.1 & $<0.001$ & 7.5 & $<0.005$ & 5.9 & $<0.005$ \\
Annual grass vs. oat & 39.9 & $<0.001$ & 10.7 & $<0.001$ & 4.4 & 0.04 \\
Barley vs. oat & 4.9 & $<0.005$ & 3.2 & 0.05 & -1.5 & 0.38 \\
\hline
\end{tabular}

${ }^{\mathrm{a}}=$ Standard error of mean

ennial grass, and $99 \%$ of the DM yield of annual grass. In oat the respective yields were $93 \%$ and $97 \%$.

\section{Metabolizable energy yields}

The MEYs of barley (52.7 GJ/ha) and oat grainyield (47.8 GJ/ha) were substantially lower than the MEYs of annual (87.8 GJ/ha) and perennial grasses (91.6 GJ/ha) (Column A in Table 3). The study also indicated that MEY of perennial sward in the third year was significantly lower than that in the first and second years (Table 3). When the grass MEY was calculated according to silage ME values and differentiated for first cut (10.9 $\mathrm{MJ} / \mathrm{kg} \mathrm{DM}$ ) and for regrowth (10.2 MJ/ kg DM), the averaged MEY of perennial grass was 87.7 
Vol. 10 (2001): 335-346.

GJ/ha during the three-years of experimentation, and $90.9 \mathrm{MJ} / \mathrm{ha}$ when only the first two years were taken into account (Column B in Table 3).

In the calculation presented in column B in Table 3, the ME of straw was taken into account in barley and oat MEY. Barley produced 75.8 GJ/ha and oat $72.6 \mathrm{GJ} / \mathrm{ha}$. The MEY of barley and oat was significantly lower that the MEY of both annual and perennial grass sward in this calculation. The study on MEY of barley and oat in WCCS production is presented in column $\mathrm{C}$ of Table 3. The MEY of barley was $77.4 \mathrm{GJ} / \mathrm{ha}$ and of oat, $78.8 \mathrm{GJ} / \mathrm{ha}$. Also in this calculation, the MEY of both annual and perennial grass was significantly higher than that of WCCS of barley and oat.

\section{Sensitivity of yield}

Species MEY sensitivity was analysed by using the simple regression model proposed by Finlay and Wilkinson (1963). The regression coefficients in the MEY sensitivity study were: 1.13 , 1.03 and 0.94 for the first, second and third year perennial grass, and 1.09, 0.82 and 0.65 for annual grass, barley and oat (in cereals ME both of grain and straw; column B in Table 3), respectively. The regression coefficients of grasses and cereals differed significantly $(\mathrm{P}<0.001)$. Figure 1 shows the MEY difference between grasses and barley and oat at different environmental conditions.

\section{Discussion}

Although MEY is a better unit than DM yield to compare productivity of crops also ME is a problematic unit because the animal performance and utilization of the same feed depends e.g. on ME concentration of the feed as well as on the diet formulation (see Moore 1994, Paterson et al. 1994, Tuori et al. 2001). Therefore direct calculation of milk yield or animal gain from the ME yields per hectare is not justified. Consequently we focused in this study on crop production aspect to assess the differences in MEY per hectare between the studied species.

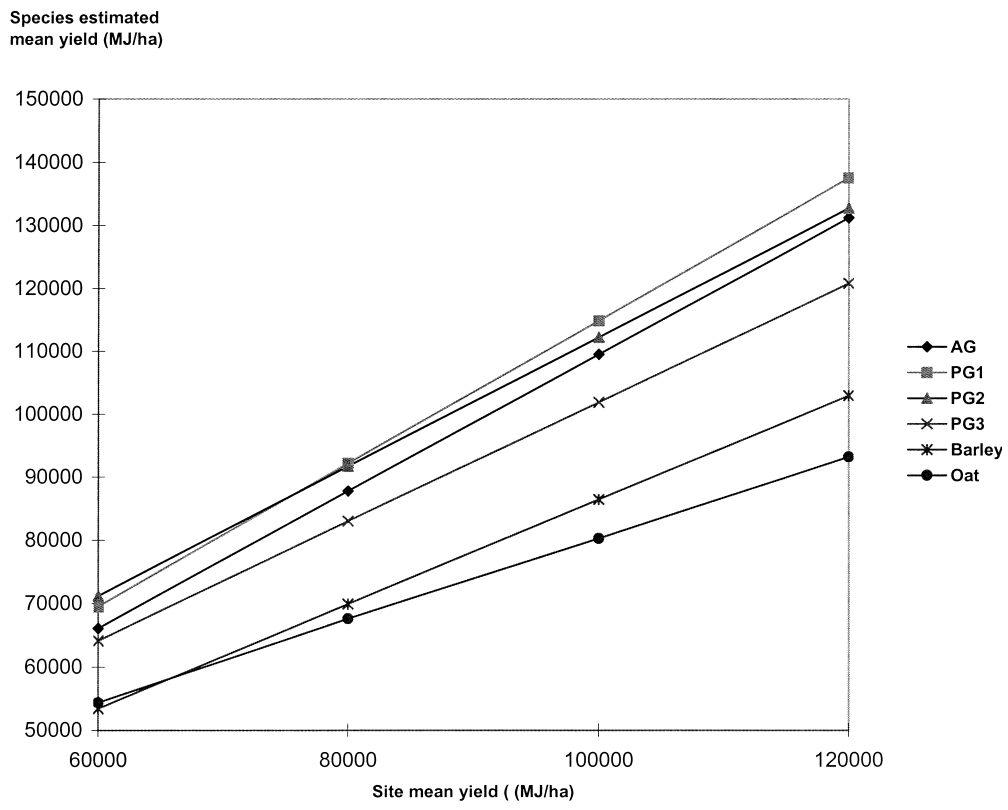

Fig. 1. The difference in metabolizable energy yield between annual and perennial grass swards, barley and oat (ME of grain plus straw) at different environmental conditions. (AG = annual grass; PG1, PG2, PG3 = $1^{\text {st }}, 2^{\text {nd }}$ and $3^{\text {rd }}$ year perennial grass). 


\section{AGRICULTURAL AND FOOD SCIENCE IN FINLAND}

\section{Niemeläinen, O. et al. Productivity of swards, barley and oats as feed for ruminants}

When interpreting the results it is vital to bear in mind the assumptions that we made. Care should be taken in interpreting the WCCS results, particularly for oat. The MEY yield of oat in WCCS was probably overestimated because the ME values of WCCS in the feed tables were based on results from barley trials. Digestibility of oat has been lower than that of barley in the WCCS production experiments (Kommeri and Kontturi 1981). Therefore, barley is considered more suitable for WCCS than oat (Kommeri and Kontturi 1981, Cherney and Marten 1982).

The HI of cereals varies from year to year, site to site, and cultivar. Few data exist on HI of barley and oat grown under Finnish conditions. The HI values of oat ranged from $40 \%$ to $60 \%$ in the study of Peltonen-Sainio (1991). In four WCCS production-trials with barley (several cultivars) the proportion of ear in the harvested DM yield was on average 72, 65, 69 and 59\% (cut at $10 \mathrm{~cm}$ stubble) (Agricultural Research Centre of Finland and Boreal Plant Breeding 1999). The proportion of grains in the ear weight was not assessed in that study. According to our experience grains constitute approximately $80 \%$ of the weight of barley ear. In this study we set the HI of both barley and oat to $50 \%$, and generated the straw yields accordingly. The HI had a strong effect on MEY in our study, as we used the HI to generate the straw and total herbage yield from grain yield. That we did not have measured data in cereals of HI and of the total herbage yield is a considerable shortage in our study. We expect, however, that the relationship between the HI and the ME content of the WCCS counter balance the effect of HI in the MEY calculation. It is likely that in WCCS the highest ME value (10.7 MJ/ kg DM in the feed table) occur in situations when the HI is high (proportion of grain is high in total yield) and the lowest value $(9.3 \mathrm{MJ} / \mathrm{kg} \mathrm{DM}$ ) when the HI is low (proportion of grain is low in total yield). When calculating the herbage mass at $\mathrm{HI} 40 \%$ from a grain yield of $3934 \mathrm{~kg} \mathrm{DM} / \mathrm{ha}$, and converting it to MEY using the lowest feed table ME content value (9.3. MJ/kg) DM for WCCS, the calculation resulted in $91.5 \mathrm{GJ} / \mathrm{ha} \mathrm{MEY}$. Using a HI of
$60 \%$, the ME concentration would reach its highest value (10.7 MJ/kg DM) resulting, however, in a MEY of $70.2 \mathrm{GJ} / \mathrm{ha}$ due to low total herbage mass in WCCS. Whole crop cereal silage is usually harvested to relatively high stubble height (8 cm and higher) with an aim to avoid contamination by soil of the silage. This will likely result in higher than 50\% proportion of grain yield in the WCCS yield, and consequently to a lower total herbage yield than in the current study. This would consequently mean that our calculation more likely overestimates than underestimates the DM yields and MEYs of WCCS.

An attempt was made to reduce the effect of cultivar in this study by using data for the same cultivar whenever possible. The variation in productivity of commercially available cultivars for the species studied is large. The chosen cultivar would have an impact on the results. The effect, would not, however, mask the large differences between the species monitored in this study. According to recent cultivar trial results (Järvi et al. 2000), the most productive new cultivars of barley, oat and meadow fescue, at most yielded 15 to $20 \%$ more than Arve, Veli and Boris, the cultivars used in this study. Use of fixed cultivars facilitates to estimate the MEY of new, improved cultivars if their yield in comparison with cultivars used in this study is known.

Harvest losses are minimal under experimental conditions compared with the farm situation. The storage and harvest losses are minimal in the cultivar trials while the yield figures for grass are based on DM measurements immediately after harvesting it. At farms, the storage losses of cereal grain are likely to be lower that those of silage, either grass silage or whole crop cereal silage, and this would increase the relative MEY of barley and oat grain at farms compared with the MEY of grass sward or WCCS obtained in this study. In the study of Ettala and Kossila (1980) the average silage DM losses were $21.2 \%$ at farms.

The study provides clear evidence that MEY of grass swards is substantially higher than MEY of barley and oat weather barley and oat were produced for grain or for WCCS. In addition, 
Vol. 10 (2001): 335-346.

the sensitivity study indicates that the perennial and annual grass swards have a good general adaptability in comparison with barley and oat. The yield benefit in favour of grasses is the greater the better growth conditions and the higher the yields are (see Fig. 1). We did not make any economical comparisons in this study. The prices of inputs and subsidies based on either European Union or national funding may have a strong effect even on short time period. Our study shows that in biological point of view perennial grass sward is the highest yielding crop of the studied crops to produce metabolizable energy for ruminants in Finland. The MEY of barley and oat grain was only $60 \%$ and $55 \%$, respectively, of the MEY of a 1-3 year old perennial grass sward. However, in the WCCS production estimate the MEY of barley was $88 \%$ of the MEY of 1-3 year old perennial grass sward. This relatively high yields of WCCS in relation to grass swards indicate that the main part of growing period is well utilized in WCCS production although spring sown crops loose very valuable growing time in spring prior to establishment.

Highly producing dairy cows do need concentrates in their diet in addition to grass silage. Grazing experiments conducted in Finland during 1969-1979 demonstrated that cows are able to produce $22-25 \mathrm{~kg}$ milk per day without concentrates when grazing good pasture and can achieve an average daily milk yield of $20 \mathrm{~kg}$ during the summer (Ettala et al. 1986). However, in intensive milk production, grass silage is supplemented with concentrate feeds of varying amount and quality. In the study of Ettala et al. (1978), the milk production rose with an increase in barley grain in the grass silage based diet. The average increase was $730 \mathrm{~g} 4 \%$ fat corrected milk per cow per day per kg barley DM. Without concentrates the average daily milk production was $14.8 \mathrm{~kg}$ per cow in their study. Rinne et al. (1999) studied the effect of the digestibility of grass silage and amount of concentrate feed on the milk production potential of silage. The same change in energy corrected milk production could be achieved by increasing concentrate intake by $1 \mathrm{~kg}$ DM per day or by improving silage digest- ibility values by $11 \mathrm{~g} / \mathrm{kg}$ (Rinne et al. 1999). Concentrate feeding, however, could not compensate for differences in silage quality.

The yield of perennial grass (meadow fescue in this study) decreased greatly in the third harvest year. This supports the findings of Nissinen and Hakkola (1995) that the yield of the most common grass species decreased strongly when the sward got older. This study indicates that the yield of annual grass was higher than the yield of perennial grass in the third year sward. However, from management point of view annual and perennial grass swards differ. The perennial grass sward produce substantial amounts of biomass in spring and early summer and produce less in late summer and autumn compared with annual grass sward (Nissinen 1992). Economical studies are needed to specify the economically recommendable age for grass swards.

Production of whole-crop silage at dairy farms, rather than a cereal harvested for grain, facilitates use of a single machinery chain both for cereals and grass silage. Decreasing the machinery costs is a key issue in lowering the costs of on farm produced feeds (Turunen 2000). Combination of WCCS and grass silage will result in better use of the capacity of silage harvesting equipment, while the harvesting of these two silages is sequential rather than simultaneous. In Finnish conditions timing of WCCS harvest is not as crucial as the first harvest of primary growth of grass silage. This promotes flexibility in harvesting schedules (Rinne et al. 1999, Jaakkola 2000). The current study indicates that the MEY yield of barley in WCCS is considerably higher than in grain production $(47 \%$ higher in our calculation). This (depending on the subsidy conditions) may increase the use of WCCS on livestock farms in the future. In Denmark WCCS is an important part of the crop rotation in dairy farms (Ohlsson 1998, Søegaard and Nielsen 2000).

In WCCS production, the harvest of silage usually takes place in early August, leaving a substantial amount of growing season after harvest. This period could be utilized in production of annual or perennial forage species established 
Niemeläinen, O. et al. Productivity of swards, barley and oats as feed for ruminants

undersown the cereal crop. Studies carried out on green manure crops, like under-sown legumes and annual grass species, represent one source of data that highlights the production potential. Kauppila (1985) reported that aftermath herbage production of forage under-sown in barley had yields in excess of $3500 \mathrm{~kg}$ DM/ha in Viikki $\left(60^{\circ} 13^{\prime} \mathrm{N}\right)$, Finland. In Edmonton, Canada, Ross and King (2001) showed that intercropping of berseem clover (Trifolium alexandrinum L.) with silage cereals (barley, oat and triticale (X Triticosecale Wittm.)) had potential to provide late season grazing. In their study, the total DM yields ranged from $11.7 \mathrm{t} \mathrm{ha}^{-1}$ to $14.5 \mathrm{t} \mathrm{ha}^{-1}$. The berseem component of the total DM yield ranged from $19 \%$ to $49 \%$.

Further economical and biological studies are required to find the most suitable strategy in feed production at cattle farms. This biological study suggests that production of grass silage and/or WCCS at dairy farms instead of combine-harvested cereal grain is recommendable. This development initiates the need to optimize grass production in conjunction with WCCS. Studies are in progress to examine the possibility to take a grass silage cut during the same season as a subsequent harvest of WCCS. Determination of the harvest index or straw yield in addition to grain yield, particularly in barley cultivar trials, would provide highly valuable information to estimate WCCS yields.

\section{Conclusions}

Perennial grass sward produced higher MEY during the first two years than an annual grass. In the third harvest year a perennial grass sward was less productive than in the first two harvest years, and produced lower MEY than an annual grass sward.

Grain of barley and oat was biologically less productive in MEY terms than either annual or perennial grass swards.

Estimated WCCS yields of barley and oat had significantly lower MEY than an annual or perennial grass sward.

The differences in MEY yield among species increased when yields increased.

Acknowledgments. The official variety testing authorities are acknowledged for providing the dataset used in this study.

\section{References}

Agricultural Research Centre of Finland and Boreal Plant Breeding 1999. Kokoviljasäilörehu maatilan viljelyresurssien optimoinnissa: viljalajin ja -lajikkeiden vaikutus rehuarvoon. (Whole crop cereal silage in optimization of the cultivation resources at farm: effect of crop species and cultivars on feeding value, in Finnish). Loppuraportti 10.5.1999. Dnro 3902/507/ 95 Maatalousosasto Maatilatalouden kehittämisrahasto. $48 \mathrm{p}$.

Cherney, J.H. \& Marten, C.G. 1982. Small grain crop forage potential: I. Biological and chemical determinants of quality, and yield. Crop Science 22: 227-231.

Ettala, E., \& Kossila, V. 1980. Orgaanisten aineiden, kivennäisten ja nitraattitypen hävikit valmistettaessa ruohosta tuoresäilörehuja. Referat: Förlusterna av organiska ämnen, mineralämnen och nitratkväve vid framställning av ensilage av gräs. Kehittyvä Maatalous 45: 18-31.
-, Lampila, M. \& Rissanen, H. 1978. Effect of concentrate feeding level in grass silage-based diets on milk production of dairy cows. Annales Agriculturae Fenniae 17: 175-185.

-, Rinne, K., Virtanen, E. \& Rissanen, H. 1986. Effect of supplemented concentrates on milk the milk yields of cows grazing good pasture. Annales Agriculturae Fenniae 25: 111-125.

Finlay, K.W. \& Wilkinson, G.N. 1963. The analysis of adaptation in a plant breeding programme. Australian Journal of Agricultural Research 14: 742-754.

Ministry of Agriculture and Forestry 2000. Maatilatilastollinen Vuosikirja 2000. (Yearbook of Farm Statistics 2000). Information Centre of the Ministry of Agriculture and Forestry. 266 p.

Jaakkola, S. 2000. Kokoviljasäilörehusta lupaavia tuloksia. (Promising results of whole crop cereal silage, in Finnish). Nauta 30, 2: 16-18. 
Vol. 10 (2001): 335-346.

Järvi, A., Kangas, A., Laine, A., Niskanen, M., Salo, Y., Vuorinen, M., Jauhiainen, L. \& Mäkelä, L. 2000. Virallisten lajikekokeiden tulokset 1992-1999. (Results of the official variety trials 1992-1999). Maatalouden tutkimuskeskuksen julkaisuja. Sarja A. 70.216 p.

-, Kangas, A., Mattila, I., Mäkelä, L., Rahkonen, A., Salo, Y., Vuorinen, M. \& Öfversten, J. 1998. Virallisten lajikekokeiden suoritusohjeet. (Guidelines for conducting official variety experiments, in Finnish). Maatalouden tutkimuskeskuksen julkaisuja. Sarja B. 14. $71 \mathrm{p}$.

Kauppila, R. 1985. Apilat aluskasveina viljanviljelyssä. Summary: Undersowing legumes for green manuring of cereals. Biologisen typensidonnan ja ravinnetypen hyväksikäytön projekti. Julkaisu 20. Suomen Itsenäisyyden juhlavuoden 1967 rahasto. 48 p.

Kommeri, M. \& Kontturi M. 1981. Kokoviljasäilörehun sadot, säilöntä ja rehuarvo. (Yields, conservation and feeding value of whole crop cereal silage, in Finnish). Kotieläinhoidon tutkimuslaitoksen tiedote 15. p. $1-28$.

Littell, R.C., Milleken, G.A., Stroup, W.W. \& Wolfinger, R.D. 1996. SAS System for Mixed Models. SAS Institute Inc., Cary, NC. 633 p.

Maaseutukeskusten Liitto 2001. Tuotanto- ja taloustarkkailu 1999. (Results from herd recording farms from year 1999, in Finnish). In: Maatalouskalenteri 2001. Maaseutukeskusten liitto. p. 192-195.

MAFF 1984. Energy allowances and feeding systems for ruminants. Reference Book 433. Her Majesty's Stationary Office, London. 85 p.

Moore, J.E. 1994. Forage quality indices: development and application. In: Fahey, G.C. et al. (eds.). Forage Quality, Evaluation, and Utilization. American Society of Agronomy, Madison, Wisconsin, USA. p. 59-113.

Neter, J., Kutner, M., Nachtsheim, C. \& Wasserman, W. 1996. Applied Linear Statistical Models. Fourth Edition. Irwin, Chicago. 1310 p.

Nissinen, O. 1992. The suitability of green forage plants for grazing in Northern Finland. Proceeding of the $14^{\text {th }}$ General Meeting of the European Grassland Federation. 8-11 June 1992, Lahti, Finland. p. 329331.
- \& Hakkola, H. 1995. Effect of plant species and harvesting system on grassland production in northern Finland. Agricultural Science in Finland 4: 479-494.

Ohlsson, C. 1998. Use of N in two cropping systems at a dairy farm in Denmark. Grassland Science in Europe 3: 819-822.

Paterson, J.A., Belyea, R.L., Bowman, J.P., Kerley, M.S. \& Williams, J.E. 1994. The impact of forage quality and supplementation regimen on ruminant animal intake and performance. In: Fahey, G.C. et al. (eds.). Forage Quality, Evaluation, and Utilization. American Society of Agronomy, Madison, Wisconsin, USA. p. 59-113.

Patterson, H.D. \& Nabugoomu, F. 1992. REML and the analysis of crop variety trials. In: Proceedings of Invited Papers, 1992 International Biometrics Conference. Hamilton, New Zealand. p. 77-93.

Peltonen-Sainio, P. 1991. Productive oat ideotype for northern growing conditions. Euphytica 54: 27-32.

Rinne, M., Jaakkola, S., Kaustell, K., Heikkilä, T. \& Huhtanen, P. 1999. Silages harvested at different stages of grass growth $v$. concentrate foods as energy and protein sources in milk production. Animal Science 69: 251-263.

Ross, S.M. \& King, J.R. 2001. Berseem clover in binary mixtures with oats, triticale or barley for silage and late season grazing. Proceedings of the XIX International Grassland Congress. Brazil. p. 738-740.

Søegaard, K. \& Nielsen, K.A. 2000. Grassland in Denmark. Grassland Science in Europe 5: 1-8.

Tuori, M., Kaustell, K., Valaja, J., Aimonen, E., Saarisalo, E. \& Huhtanen, P. 2001. Rehutaulukot ja ruokintasuositukset 2001. (Feed tables and feeding recommendations, in Finnish). Jokioinen: MTT. Updated 2 April 2001. Cited 2 April 2001. Available at: http:// www.mtt.fi/julkaisut/rehutaulukot/. URN:NBN:fife20011096.

Turunen, H. 2000. Kokoviljasäilörehun viljelyn tuotantokustannukset ja kannattavuus maidontuotannossa. Summary: Production costs and profitability in the cultivation of whole crop silage in milk production. Maatalouden taloudellinen tutkimuslaitos. Selvityksiä 6/2000. $55 \mathrm{p}$. 
Niemeläinen, O. et al. Productivity of swards, barley and oats as feed for ruminants

\title{
SELOSTUS
}

\section{Yksi- ja monivuotisen nurmen, ohran sekä kauran muuntokelpoisen energian sadot märehtijän rehustuksessa lajikekokeiden tuloksista estimoituina}

\author{
Oiva Niemeläinen, Markku Kontturi, Lauri Jauhiainen ja Oiva Nissinen \\ MTT (Maa- ja elintarviketalouden tutkimuskeskus)
}

Tutkimuksessa verrattiin yksi- ja monivuotisen nurmen, ohran sekä kauran satoisuutta muuntamalla virallisista lajikekokeista saadut kuiva-ainesadot muuntokelpoisen energian sadoiksi (MES) märehtijän rehutaulukkoarvojen avulla. Lähtöaineistona oli virallisten lajikekokeiden tulokset vuosilta 1976-1998 niiltä koepaikoilta, joilla vähintäin kolme tutkituista lajeista oli ollut samanaikaisesti kokeissa. Tuloksia oli yhteensä viideltätoista koepaikalta. Nurminadan tulokset olivat lajikkeelta Boris, italianraiheinästä lajikkeilta Barmultra ja Mitos, kaurasta lajikkeelta Veli ja ohrasta lajikkeilta Otra, Arra ja Arve. Viljojen lajikekokeissa ei mitata olkisadon määrää. Olkisato tuotettiin satoindeksillä $50 \%$ jyväsadon tuloksia apuna käyttäen.

Kolmantena nurmivuonna MES (81,4 GJ/ha) oli pienempi kuin ensimmäisenä $(90,0 \mathrm{GJ} / \mathrm{ha}) \mathrm{ja}$ toisena nurmivuonna (90,7 GJ/ha). Keskimäärin monivuotinen nurmi tuotti suuremman ME-sadon kuin yksivuotinen nurmi (87,7 vs. 83,3 GJ/ha). Sekä yksi- että monivuotisen nurmen MES oli suurempi kuin ohran (52,7 GJ/ha) ja kauran (47,8 GJ/ha) jyväsadon MES.
Kun myös oljen muuntokelpoinen energiasato (ME arvolla $6,0 \mathrm{MJ} / \mathrm{kg} \mathrm{KA}$ ) otettiin huomioon jyväsadon lisäksi oli ohran MES 75,8 GJ/ha ja kauran 72,6 GJ/ ha. Kun ohran jyvä- ja olkisadolle annettiin kokoviljasäilörehun energia-arvo $(9,9 \mathrm{MJ} / \mathrm{kg} \mathrm{KA})$, oli ohran kokoviljasäilörehusatoa kuvaava MES 77,4 GJ/ha, joka oli alhaisempi kuin yksi- ja monivuotisen nurmen MES. Ohran MES oli a) $60 \%$, b) $86 \%$ ja c) $88 \%$ monivuotisen nurmen keskimääräisestä MEsadosta, kun ohran MES oli laskettu a) jyväsadon, b) jyvä + olkisadon ja c) kokoviljasäilörehusadon perusteella.

Tutkimuksen mukaan nurmi on Suomessa selkeästi rehuviljaa satoisampi muuntokelpoisen energian tuottaja märehtijän rehustuksessa. Kirjoituksessa pohditaan tutkimuksessa käytettyjen olettamusten vaikutusta laskelmien luotettavuuteen. Satoindeksin ja/tai olkisadon määrittäminen lajikekokeissa, erityisesti ohrakokeissa, jyväsadon ohella lisäisi lajikekoetulosaineiston käyttökelpoisuutta lajikkeiden satoisuuden arvioimiseen kokoviljasäilörehuksi viljeltäessä. 